\title{
The Rise of Social Movements Among Migrant Workers
}

Uncertain strivings for autonomy

Chloé Froissart

\section{OpenEdition}

\section{Journals}

Édition électronique

URL : http://journals.openedition.org/chinaperspectives/526

DOI : 10.4000/chinaperspectives.526

ISSN : 1996-4617

Éditeur

Centre d'étude français sur la Chine contemporaine

Édition imprimée

Date de publication : 1 octobre 2005

ISSN : 2070-3449

\section{Référence électronique}

Chloé Froissart, «The Rise of Social Movements Among Migrant Workers », China Perspectives [En ligne], 61 | september-october 2005, mis en ligne le 01 octobre 2008, consulté le 28 octobre 2019. URL : http://journals.openedition.org/chinaperspectives/526 ; DOI : 10.4000/chinaperspectives.526

Ce document a été généré automatiquement le 28 octobre 2019

(C) All rights reserved 


\title{
The Rise of Social Movements Among Migrant Workers
}

\author{
Uncertain strivings for autonomy
}

\section{Chloé Froissart}

1 The reforms brought with them the Party's retreat from certain social and economic spheres, and what was once claimed as identical interests between the Party-state, the working people and the enterprise administrators vanished. As Dorothy J. Solinger puts it in a recent paper: the three parties, "once supposed allies, have become mutually antagonistic"1. The economic reforms hence enabled the emergence of a new space where social, economic and political actors have a chance to push for their interests thanks to new conditions of bargaining as well as new alliances. According to Charles Tilly, "social movements contribute to the creation of a public space-social settings, separate both from governing institutions and from organizations devoted to production or reproduction, in which consequential deliberation over public affairs takes place-as well as sometimes contributing to transfers of power over states"2. Peasants were the first among the Chinese population to be put on the move by the economic reforms: transient, no longer belonging to rural society and lacking residency status in the urban area where they work, while more immune to social control they are also denied full citizenship rights. This situation changed in 2002-2003 when the central government, aware both of the necessity to acknowledge migrant workers' economic contribution and afraid of growing social instability, started to call for the protection of their "legal rights". However, as the state is trying to regain migrant workers' confidence in an attempt to reassert its legitimacy, some migrants now want autonomy. They are supported by social organisations willing to fill the gap created by an unsupportive Party or to provide some redress against an oppressive system. This situation recalls the definition of social movements as "a network of informal interactions between a plurality of individuals, groups and/or organizations" ${ }^{3}$. As Tilly reminds us, a social movement is not a group of a particular sort, "nor do social movements undergo natural histories" ${ }^{4}$ with a starting point, a middle and an end. They are rather defined as historically specific clusters of political performances. The aim of this article is to determine why the social movements that have recently 
appeared among migrant workers emerged at that specific moment and how the historical moment in which they arose contributed to their specificity. It will then further explore what it is that shapes the migrant workers' social movement in an attempt to evaluate their impact on state-society relations. Do migrants challenge established social and political values? Migrant workers are now increasingly resorting to new forms of action and representation, but does this mean that they are emerging as an autonomous group?

How the Chinese state's emerging legal discourse informs social movements

The state's changing discourse towards migrant workers abetted their political expression of their grievances and informed the emergence of social movements.

The state's changing policy towards migrant workers and its implementation at the local level

3 The years 2002-2003 symbolise a turning point in the attitude of the Chinese government towards migrant workers. Until then, the central government had mainly turned a blind eye to the way urban authorities had taken advantage of the Chinese residency system not to grant any rights to migrant workers, and had increased the economic and administrative hurdles to prevent a "blind flood of migrants" (nongminggong mangmu liudong) into urban areas. In 2003 however, a number of important policies were issued by the central government that called for the protection of migrant workers' "legal rights". Three main reasons explain this sudden change. The first reason is that a new political leadership came to power and designed new priorities for national development. Since the Sixteenth Congress of the Chinese Communist Party in November 2002, the leadership has put an emphasis on new social policies in favour of the disenfranchised and on restoring the socio-economic balance between rural and urban areas. It acknowledged that migrant workers' remittances to villages represented a vital support to the rural economy and as such needed to be secured. The second reason for the central government's changing attitude was the need, since the 1990s, to tackle increasing delinquency and criminality among migrant workers and to preserve social order. The third reason, according to nationwide surveys, is that migrant workers already represent $60 \%$ of the workforce in the secondary and tertiary sectors ${ }^{5}$. They were thus acknowledged as the "majority of the working class" (gongren de zhulijun). They therefore should enjoy rights commensurate with their growing contribution to national development.

4 Following these acknowledgments, the State Council issued a decree on Successfully Managing the Employment of Rural Workers in the Cities and their Access to Public Services in January 2003, as well as the First Political Document ${ }^{6}$ in January 2004. Both documents call for the eradication of any kind of discriminative regulations or practices against migrant workers. The documents also request an equal access to employment, education and public services. The central government thus insists that the national law is universal, and should protect everyone equally, prevailing over the administrative system-including the hukou (residency registration) system-inherited from the Maoist period, as well as over local regulations. This claim was followed by a demand to facilitate migrant workers' access to state institutions, tribunals and Party organisations in an attempt to channel their grievances into legal redress. In August 2003, an urgent circular was issued by the All China Federation of Trade Unions (ACFTU) to urge migrant workers to join the trade unions, a right that, in practice, they had often been denied thus far ${ }^{7}$. Besides trying to foster local authority responsibility 
towards migrants, the central government launched a campaign in October 2003 to develop their professional and legal training, assuming that the violent actions by migrants could be explained by their "backwardness" and their lack of legal culture.

5 I will study the case of Chengdu, the capital of Sichuan province, to see how these central directives were implemented at the local level. There, they were strictly followed. The provincial government issued local regulations to echo them. For example, the Supreme Court of Sichuan issued a circular urging tribunals at every level to expedite the investigation, the trial and the enforcement of court decisions regarding any cases involving migrant workers. It also called for the reduction or the exemption of trial fees ${ }^{8}$. The provincial Labour and Social Security Bureau, the provincial Construction Bureau and the provincial branch of the ACFTU jointly issued a notification compelling construction companies to pay a bank deposit to guarantee migrant workers' salaries'. The municipal government also launched a political campaign highly supported by the media to raise rights awareness and knowledge of legal procedures among migrant workers, and encourage them to "trust the government, trust the law"10. Governmental institutions were portrayed as siding with the migrants, settling conflicts free of charge in an efficient and fair manner and checking if their employers had signed labour contracts, paid migrant salaries, and contributed to migrant social security ${ }^{11}$. The Sichuan branch of the ACFTU distributed a great number of flyers to inform migrant workers of their rights, the role of the trade unions and the different kinds of procedures (conciliation, administrative arbitration and trial) available to resolve labour disputes. The central programme for the legal training of migrant workers led to the mushrooming of training sessions organised by governmental agencies at every level, mass organisations, social organisations and socalled "Government Operated Non Governmental Organisations" (GONGOs) ${ }^{12}$. In 2003, the Sichuan provincial government trained 2.1 million migrants and announced that 10 million would be trained by 2005. Public funding for this programme in Sichuan amounted to 4 million yuan in 2003 and 71 million in $2004^{13}$.

6 Local authority eagerness to follow the central directives is due to particular conditions in the Sichuan capital. First, as more than $90 \%$ of migrant workers in Chengdu are from Sichuan province, the municipal government's administrative responsibility towards Sichuanese migrants is much stronger than the responsibility of big coastal cities towards migrants from all over China. At least, the provincial government can put pressure on the municipality and compel it to better protect migrant workers' rights ${ }^{14}$. For this reason, working and living conditions for migrants have been traditionally better in Chengdu than in big coastal cities. Second, Chengdu First Party Secretary Li Chuncheng made the "unification of urban and rural areas" the new motto of the municipality and committed himself to bring peasants and migrants' rights in the line with those of urban dwellers ${ }^{15}$.

Confronting official discourse with unchanged conditions: from rights awareness to political consciousness

7 As a result of this new policy, rights awareness among migrant workers improved greatly, as did their inclination to seek legal redress. Migrant workers trained in NGOs were very satisfied with the legal knowledge they had acquired. As L, a young migrant volunteer in a Shenzhen NGO, put it: "Only after attending the classes did I know that overtime should be paid, that when you get hired by a company you are not supposed to pay a deposit to your employer but you are supposed to sign a work contract with 
him". Training also helped migrant workers to broaden their claims and to seek equal treatment with urban or more qualified workers. In the past, complaints were mainly about the payment of salaries, but claims now also concern social security enrolment, holiday or professional training ${ }^{16}$. All the legal aid centres I surveyed ${ }^{17}$ reported a dramatic increase in the number of migrants seeking advice on how to take legal action against their employers.

Despite a nationwide political campaign, the protection of migrant workers' rights did not, in fact, improve dramatically. According to workers' statements, working conditions in factories did not change: unpaid salaries, long-unpaid overtime, lack of respect for security norms, frequent industrial accidents, absence of social security or support from the employer in case of injuries at work or diseases contracted within a work environment are still the lot of migrant workers ${ }^{18}$. Likewise, many workers still complain about being forced to rush from one review office to another and the difficulty of getting cases accepted due to the collusion between authorities and entrepreneurs. Delays in trial or enforcement of court decisions as well as arbitrary and steep procedural fees are also subjects of contention. Some workers still do not dare sue their employer for fear of losing their jobs or other forms of reprisal ${ }^{19}$. There are still cases of migrants who have been physically abused ${ }^{20}$ or even murdered ${ }^{21}$ for seeking salary compensation. In August 2004, a year and a half after the launching of the first political campaign to clear back pay, Vice-Premier Zeng Peiyan revealed that more than 360 billion yuan in unpaid wages remained owed to migrant workers ${ }^{22}$. As a result, Chinese and foreign media are still regularly reporting on migrants committing suicide by jumping from the towers they helped to build ${ }^{23}$, by blowing themselves up ${ }^{24}$ or by self-immolation ${ }^{25}$. Mass riots have also recently increased in scope, violence and duration.

9 In the short term, the revised discourse of the Chinese leadership had a positive impact. It appears to show the state and the Party siding with the workers, sharing the same interests and fighting against the illegal practices of entrepreneurs or corrupt local officials. What is under attack are individuals not the system. Indeed, the populist tactics of China's new leaders, the political campaigns in 2003 and 2004 to help migrant workers claim back their overdue wages and the thundering announcements of the billions of yuan that have been paid back to them have had quite a strong symbolic impact over migrants. At first, they were thankful for this public acknowledgment of the legitimacy of their claims. In December 2003, the Peking municipality supported a show trial against a construction company that owed over 5 million yuan to a 500strong migrant worker team, but the court decision was difficult to enforce since the company did not have enough money to pay the wages ${ }^{26}$. As a migrant who was a member of the worker team reported to central television: "It's such an honour for us that the government is paying attention to our case, whether we get the money back or not, the most important thing is that the authorities are on our side"27.

But when migrant workers come to understand that government practice does not match official policies and that political campaigns make little change in their daily life, they start to question the state's legitimacy, as shown by the following quotes ${ }^{28}$ :

11 'Newspapers spent their time reporting that migrants' salaries must achieve the minimum wage, the government also says that supervision should be reinforced to check illegal practices such as no back pay or overtime, but it's very hard to implement. 
Once out, a newspaper is already out of date and the government doesn't stick to its word-why?"29.

"What matters is not that there is no law to rely on, but that the law is not reliable, its implementation is not strict and infringements have no limits" 30 .

The opening of state institutions, courts and Party organisations to migrant workers enabled them to experience in an unprecedented way their contention with the state, which claims for the first time to serve them. Some migrants no longer explain their contention with the authorities by their specific status as unwanted guests in the cities, but by the failings of the political system that affect them as well as other social categories who lack both the economic and social capital to get round these failures. Migrants are experiencing a paradoxical situation where their rights, acknowledged both by the law and the state's policy statements, are not guaranteed, yet the discourse of the central authorities gives them new incentive and the possibility of expressing their claims. As in Western countries, social movements in China can be defined in terms of the challenges they pose to established norms and values ${ }^{31}$. The difference in China is that the law is mobilised to question social codes and practices that commonly occur and are made possible by China's institutional system.

Challenging the discourse of the Party-state

14 As James C. Scott recalls, the very basis on which claims to legitimacy are advanced provides "the raw material for contradictions and conflicts" 32 in a society: "the very process of attempting to legitimate a social order by idealizing it... provides its subjects with the means, the symbolic tools, the very ideas for a critique... For most purposes, then, it is not at all necessary for subordinate classes to set foot outside the confines of the ruling ideals in order to formulate a critique of power" ${ }^{33}$. This is particularly true in the Chinese case where strongly oppressive regimes always deterred people from directly confronting the political system. During the Cultural Revolution, some factions of the Red Guards effectively opposed the Maoist regime while apparently endorsing the official revolutionary ideals. They were denounced as the ones who were "using the red flag to fight the red flag" ${ }^{34}$. The same tactics are still used today by migrants who turn back the official discourse against the state. As we saw previously, the new leadership's populist tactics aim to regain migrant workers' confidence in the government's capacity to preserve social order and to rule with benevolence. These are, as recalled by Vivienne Shue ${ }^{35}$, two main grounds on which the CCP claims its legitimacy. Migrants' repertoire of contention refers to the same values held by the state that are either questioned or reassessed in an attempt to compel authorities to comply with them. Facing difficulties in suing their employers, migrants would, for example, refer to the law they thought was infringed and say "Why doesn't it apply to us? Aren't we citizens of the People's Republic of China?", and “We're making a great contribution to national development, our rights should be protected", or "I respect the society where I live and work, I expect it to respect me in return".

15 A strike that was successfully carried out in a Shenzhen factory in October 2004 is an example of how migrants are putting the state to the test. This example shows how migrants refer to the law both to try to rally local officials against the factory management and to put pressure on the authorities so that they enforce the law they promulgated. A month after the strike broke up, I went to Hai Yan Electronic Plant, a Hong Kong-Guangzhou joint-venture manufacturing electronic components, to gather worker testimonies. In this factory, the workers were paid 240 yuan monthly for a 
regular working day of 12 hours, and 15 hours during peak times, seven days a week. Since the fixed salary was very low, they regularly did overtime, although it was paid only 2 yuan an hour. Workers had also to pay for their accommodation and food. There was no trade union branch in the factory, and none of the complaints lodged by workers to the management and government offices were accepted. Workers resigned themselves to this impasse until the day they found that the Shenzhen municipality government had fixed the monthly minimum wage at 610 yuan. The news spread quickly. The workers decided to organise collective action and printed flyers that were posted in the dormitories as well as distributed by hand. Three thousand workers went on strike on October 6th for one day and a half, and the morning of the second day, they took to the streets and blocked the main highway linking Shenzhen to Hong Kong for four hours in an attempt to push the government to intervene. They were successful. Although the demonstrators were forced back to the factory by armed policemen, officials from the municipal and district Labour and Social Security Bureaus held negotiations with workers' representatives and both managements from China and Hong Kong and were compelled to enforce the legal minimum wage. Workers obtained a $170 \%$ increase on their salaries. Overtime is now paid 5.4 yuan per hour from Monday to Friday and 7.2 yuan per hour on weekends and national holidays, and is limited to 40 hours a month. Finally, the management has to contribute to workers' social security.

The main reason why this strike was successful was its wide coverage by the local press. It was the Guangzhou press, especially the outspoken Nanfang Dushibao that first reported the demonstration and hence forced Shenzhen newspapers to mention it. As the latter are directly under the control of Shenzhen authorities, they were rather scathing about the strike, and denounced it as an illegal action inducing social disorder ${ }^{36}$. But the Nanfang Dushibao sided with the workers and pointed to local authority responsibility in the demonstration: since the complaints lodged by workers in the past had been rejected, there was nothing left but to take to the streets ${ }^{37}$. Chinese media are now increasingly reporting on strikes, and whether the reports are sympathetic to the workers or not, they put pressure on local authorities to settle disputes $^{38}$. The press reports led to many postings on the Internet, most of them accusing the local authorities of failing in their duty and to support the workers' collective action ${ }^{39}$. Local NGOs also supported the migrants. One of them, the Shenzhen Institute of Contemporary Observation, explained to the local authorities that if workers had taken to the streets, it was not to create social disorder but to express legitimate claims ${ }^{40}$. This pressure obliged the police to free the two leaders of the demonstration arrested two weeks before, and the labour authorities imposed a record fine of nearly 2 million yuan on the factory management, thus enacting an exemplary punishment ${ }^{41}$.

The economic context was also favourable to the successful resolution of the strike. The Pearl River Delta had been suffering since March-April 2004 from a workforce shortage that local authorities had recently publicly acknowledged. Since the media frequently related this shortage to bad working and living conditions in the factories, local authorities were forced to take measures to better protect migrant workers' rights. They also had to face the pressure of foreign companies and joint ventures worried about their public image who were seeking to enforce the "corporate codes of conduct" in the Chinese factories that produced their goods ${ }^{42}$. The Hong-Kong based Computime Ltd was indeed favourably disposed to increase the salaries and had encouraged in the 
past its Chinese counterpart to do so, but the later was reluctant to comply. As a result, the Hong Kong party was allowed to participate in the factory social management after the strike ${ }^{43}$. The Shenzhen authorities were thus forced to change their tactic to attract foreign investments and companies: whereas they had previously depended on an abundant cheap labour, they now had to make the most of social stability and economic efficiency.

The Hai Yan factory strike was successful thanks to connections and alliances between different social actors supporting the same values. These connections were made possible by the fact that, in this particular case, local authorities and social actors were to some extent sharing the same interests (economic development, social order). This strike illustrates Tilly's definition of social movements as the shaping of a public space where a consequential debate over public affairs takes place, although the public space in the Chinese context can exist only under certain circumstances and is not institutionalised. This strike is thus a good example of the emergence of a new, and previously unacceptable, cluster of performances that marks the definitive appearance of the social movement as an available means of contention ${ }^{44}$.

19 If this case shows that migrants attempt to both rally authorities and force them to shoulder their responsibility, there are also examples of growing distrust of the Partystate among migrant workers who now seek support outside the Party framework.

Growing distrust of the Party-state and the quest for new forms of representationTrade unions as illegitimate means of representation

20 In Sichuan, the growing distrust of the Party-state is clearly demonstrated by the failure of official trade unions to attract migrant workers. As we have mentioned above, the ACFTU waged a nationwide campaign in 2003 for urging migrant workers to join trade unions. Starting from 2004, the Sichuan branch of the ACFTU was prompted to act by a series of tragic incidents involving migrant workers. The ACFTU placed concerted efforts in attracting migrants to trade unions especially designed for them. Their objectives are the following. First, provide migrant workers with professional and legal training; channel and control migration. Second, protect migrant workers' rights outside their place of origin by creating a network between scattered Sichuanese migrants and the trade unions in their villages on the one hand, and between the trade unions in the place of origin and the urban trade unions on the other hand. The aim was to fight the "local protectionism" of urban trade unions not receiving migrants' complaints in order to protect local economic interests. Third, strengthen migrants' attachment to the Party by persuading them that they are unable to defend their rights independently ${ }^{45}$.

21 Two union branches were created for migrants in 2004, one in July in Pengzhou municipality Danjing township, 40km north of Chengdu and one in October in the migrants' labour market in Chengdu: both are patent failures. Two-thirds of the population of Danjing township are farmers and 1,300 peasants are officially seeking jobs outside their native villages every year. The union was founded just after a conflict over unpaid salaries involving migrants from Danjing in north Xinjiang, which cost one of them his life. Union officials informed the Party secretaries and the village heads, and asked them to mobilise the peasants to attend a meeting to introduce to them the trade union. Despite the political campaign, only a hundred people attended the meeting and 21 became union members. When I went to survey the union situation in November 2004, members only numbered 82, although membership was free. 
According to a high-ranking official from the Department of Female Workers of the Sichuan Province General Trade Union, when officials went to the villages to introduce the union to migrants and recruit members, peasants thought they wanted to kidnap them and sell them in Xinjiang! As explained by this official: "Migrant workers have so many experiences of being cheated that they don't trust any [state] organisation that want to help them" ${ }^{46}$.

Migrants still have good reasons not to trust official organisations. In Danjing, I met a worker who came to the union building to seek conciliation in a conflict with his employer over a work accident. He was working in a mine that collapsed over him and had been classified as ninth-degree handicapped ${ }^{47}$. His employer paid for part of the medical fees, but he himself had to pay for his nursing, accommodation and food in hospital, for which he was seeking reimbursement as well as the payment of his injury compensation. According to the Regulations on Industrial Accident Insurance ${ }^{48}$, he should have received 20,000 yuan compensation, plus other reimbursements. But during the conciliation meeting held the following day in the presence of the worker, his employer and the trade union representative, the latter offered the migrant 8,000 yuan, telling him that if he went to an administrative arbitration organ or to court to seek legal redress, his complaint would not be received. This example shows collusion between trade unions and entrepreneurs (from which the trade union often takes bribes), and between trade unions and legal organs. This also explains why workers, whether urban or rural, do not trust them.

In the Chengdu migrant workers labour market, the situation was even more desperate: only one month after its foundation, the trade union branch had already been closed ${ }^{49}$. Migrants were scathing about the union: "No point to seek trade unions' help. They take your money and run", "Trade unions serve the capital, not the people", "Trade unions are full of conmen, and they never settle conflicts" were widespread statements. Migrant hostility towards the trade union can be explained by the specific situation of the labour market, which is under the jurisdiction of the urban district government but in reality functions on a purely private and mercantile logic, a situation the market administration takes advantage of. Huge amounts of money are extorted by the employment agencies from the workers who cannot find proper jobs. Hence, migrant workers equate the trade union with the administration and the private agencies. But they also remember their experience in the cities, where they were often subject to arbitrary official extortion. Some did not believe in the longevity of the effects of the leadership's new policy that put an end to arbitrary raids and detentions and lowered the price of the various permits that migrant workers have to purchase to live and work in the cities. Others said about the campaign on back pay clearance: "It is not enough to issue new policies, they have to be enforced". During this interview, migrant workers were clearly questioning the Chinese political system and the Party's legitimacy by denying their capacity to protect their rights, govern with benevolence and preserve social order. This situation already led some migrants to seek support from so called "non governmental organisations" founded and run by urban people, or even to create their own organisations.

New forms of representation within the political system

Social organisations have developed in China these past few years, providing social services that the Party and the state did not want to or could not provide at first. The ones devoted to serving migrants offer a social space to isolated workers, also 
professional and legal training, general and health education and advice on life in the city. They also provide legal aid and offer free conciliation services. They facilitate migrants' access to administrative arbitration and tribunals by giving procedural advice, helping build up a judicial record, providing free or low-rate legal services. These organisations operate as a substitute of distrusted official trade unions. More and more migrants are seeking their help or are working for them as volunteers during their free time. Many workers admitted that they would never have obtained or even sought legal redress without the help of these organisations. Hence, these groups force public institutions to take workers' grievances into account and they also try to influence public policies by submitting reports to the state or organising consultative conferences.

The state had to acknowledge the growing influence of these organisations by issuing and regularly reviewing regulations concerning NGOs. Paradoxically, as the regulations ${ }^{50}$ stipulate that to be registered with the Ministry of Civil Affairs as an NGO, an organisation has to be sponsored by a state organ, very few organisations are granted official status and the ones that are cannot be considered as truly nongovernmental. Three kinds of organisations can be distinguished according to their degree of autonomy as well as their work and political orientation.

First, the Government Operated Non-Governmental Organisations (GONGOs). Initiated by a state organ that supervises them, they have legal status and receive public funds. They thus can be considered an extension of the state. Indeed, they do not differ much from state agencies that channel migrations and recruitments and train the migrants. GONGOs mainly focus on improving migrant workers' economic and so-called "legal rights" in the framework designed by the Communist Party. I surveyed two of them. One, located in Chengdu, is called West China Sichuan Relief Centre for Migrant Workers (Sichuan Huaxi nongmingong qiuzhu zhongxin), and was founded in 2003 by one of the leaders of the provincial government agency for the development of the workforce linked to the Sichuan Province Bureau of Agriculture. It clearly acts as a trade union: it directly intervenes with employers and local authorities to settle disputes involving Sichuanese migrants. It also compensates for migrant workers' lack of social security by granting them a lump sum in case of emergency or in compensation to disability related to an industrial accident. The other, in Peking, is called the Migrant Women's Club (Dagongmei zhi jia). It was founded in 1996 by the chief editor of the National Federation of Women's publishing house and is supported by a famous representative of the Peking Municipality People's Congress who is a member of its management committee. However, this organisation is growing more independent in its funding sources and initiated advocacy meetings attended by academic specialists, social workers, representatives of migrant workers, high-ranking officials and cadres of mass organisations, to discuss the possibilities of improving state policies for migrant workers.

Second, the NGOs set up by urban residents and not directly related to a state organisation, although they often have many governmental connections. Beijing Facilitator (Beijing xiezuozhe) is one of those. It is registered as an enterprise with the municipal Bureau of Industry and Commerce and is entirely financed by foreign organisations. It was founded in 2003 by two defectors from Migrant Women's Club who wanted to promote a more democratic organisation relying to a greater extent on migrants' active and direct participation. Beijing Facilitator aims to foster class 
consciousness by organising activities in small groups led by migrant volunteers who share experiences, analyse the difficulties they face in the city, and promote solidarity among migrants. This organisation claims to be closer to the people and more legitimate as its founders do not have a Peking hukou and as part of their family members are from the countryside. It also claims to be more involved in promoting "civil society" by influencing public policies than the previous one. However, because of both political constraints -especially the necessity to secure an uncertain status- and its cultural heritage this organisation also appears to some extent as a transmission belt of the Party-state, fostering official ideology among migrant workers and exerting a kind of social control over them ${ }^{51}$.

Third, NGOs run by migrant workers who think that migrants should only rely on themselves to defend their rights. They are registered as enterprises with the Bureau of Industry and Commerce and are exclusively financed by foreign NGOs. The more radical organisation we met is located in Shenzhen. Its leader is quite sceptical about the previous organisations that "do not promote autonomous development of migrant workers as a group." ${ }^{2}$. He views these organisations as "Counsellors to the Prince" beholden to the state and as illegitimate representatives (being urban, non elected, close to power) of a population deprived of any direct means of political expression. According to his point of view, trying to orientate reforms by advising the state is tantamount to acknowledging its legitimacy and the legitimacy of the current system as a whole. The organisation mainly spreads legal and job security information among workers, and provides assistance to those who want to lodge complaints against or sue their employer. But the ultimate aim of this association is to help migrant workers gradually unite and organise to eventually change the political system through collective actions. This kind of radicalism is closely linked to the characteristics of Shenzhen, which is far away from the Centre and where migrant workers are concentrated in industrial districts, thus having little connection with the local urban population. Workers in Shenzhen generally join labour organisations because they are aggrieved and eager to defend their rights, whereas many members of the Peking organisations mentioned above are employed in the service sector and are also looking for a place of sociability and an opportunity to improve their general knowledge. More importantly, migrants' NGOs in Shenzhen have close relations with foreign labour groups, especially the ones based in Hong Kong that act as counsellors and supervisors to these organisations.

However, as NGOs run by migrant workers are politically very sensitive and are even more likely than other organisations to be banned at any time, they often have no choice but to agree to some kind of collaboration with the state. This is the case of The Home of Fellow Peasants (Nongyou zhi jia), a Peking-based organisation more oriented towards pedagogic and cultural activities, whose leader was elected "Nationally outstanding young migrant worker" in May 2005 because he had given information to state organs about migrant workers. This is a good example of how the Party tries to co-opt activists that otherwise might become dissidents, by giving them the feeling they can act more efficiently if they contribute to reform the system from inside ${ }^{53}$. The deal is the following: relative security is granted to these organisations as long as they accept to side with the government.

There is hence growing rights awareness among migrant workers that sometimes can give birth to political consciousness; but this political consciousness is still hardly 
translated into an increased autonomy for society. So-called NGOs, also officially labelled "third sector", offer migrant workers services that the state does not provide for lack of resources or lack of will. They fill the gap in the political system without opposing it, thus contributing to perpetuating the status quo. This is the extent to which Chinese social movements fail to match Tilly's definition. First, our study of the third sector reveals that the delegation of Party-state responsibilities to the NGOs does not give rise to the empowerment of the society. Second, NGO's advocacy commitment shows the limits of their political demand and their lack of strategy to overcome this collaboration pattern and shift the power balance in favour of society. At least one NGO is already aware of these limits, but its ability to induce a new political dynamic appears in itself limited. First, it is not self-reliant and admits the difficulty of mobilising migrant workers on a sustained basis. Second, given the political constraints, it also subscribes to the idea of reforming the system from inside. Its strategy mainly consists in encouraging migrants to sue their employers as a way to boost workers' legal training and add pressure on the authorities. Third, it is very reluctant to establish connections with other organisations. There are supposedly a couple of migrants' NGOs in the Pearl River Delta. They know each other since the same foreign foundations support them but they are reluctant to unite, knowing that it is the surest way to be suppressed.

Social movements among migrant workers in China emerged because of the contradictions of the state that wanted to preserve social order without consenting to core political reforms. Rights awareness among migrants was at first encouraged by the central government, which urged state organisations to protect migrants' rights and foster their legal training. The recourse to legal procedure fostered individualisation but maintains conflict in the private sphere: which is why it was allowed by the regime. However, this is the phase during which migrants fully experienced their disempowerment and the failings of the system. Confronting this failure revealed the necessity of reforms and the need to find alternative forms of redress outside the Party-state. The Chinese state's efforts to maintain social order and regain migrant confidence thus provided for the emergence of social movements, and gave them their rhetorical content. A new form of mediation and representation, such as the NGOs discussed above, appeared for the first time. These organisations are already playing the role of public organs, such as trade unions, lobbying the authorities in the name of migrants to foster the guarantee of their rights. But these organisations, whose autonomy is not institutionalised, face difficulties promoting alternative values and prevent to some extent the emergence of disgruntled migrants as an autonomous actor capable of contributing to political life. NGOs are thus also working for the benefit of the Party-state, to which they adhere, minimising social conflict and orienting reforms in a direction that can help the Party to maintain its power. While an integral part of the social movement of migrant workers, these organisations also delimit this social movement in their own way. These delimitations are why some migrants question these NGOs' legitimacy to represent them-which might be migrant workers' first step towards a more assertive and autonomous stand. 


\section{NOTES}

1. Dorothy J. Solinger, "The new crowed of the dispossessed, The shift of the urban proletariat from master to mendicant", in Peter Hays Gries and Stanley Rosen (ed.),

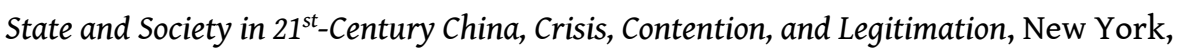
Routledge Curzon, 2004, p. 61.

2. Charles Tilly, "Social Movements as Historically Specific Clusters of Political Performances", Berkeley Journal of Sociology, 1993-94, vol. 38, p. 1.

3. Ibidem, p. 5.

4. Ibid, p. 6.

5. "Guanzhu chengwei chanye gongren zhongyao zucheng bufen de nongmingong" (Paying attention to migrant workers who have already become an important part of the productive workforce), Zhongguo danggai ganbu luntan (Officials' Forum for the Reform of the CCP), No. 4, 2004, p. 16. According to Liu Kaiming, an independent research head of the Shenzhen NGO Institute of Contemporary Observation, in 2003 migrants represented $57 \%$ in the manufacturing sector, more than $80 \%$ in the construction sector and 50\% in the service sector; Mingong yu gaige jingcheng (Migrant Labor: The Internal Power of China's Reform), unpublished paper presented at the conference Nongminggong gonggong zhengce yu fuwu chuangxin (Public Policy Reform and Service Innovation for Migrant Workers) organised by the NGO Beijing Facilitator, Peking, November 2004.

6. Guowuyuan bangongting tongzhi, Zuohao nongmin jincheng wugongjiuye guanli he fuwu gongzuo, January 16th 2003, and Guowuyuan bangongting, Yihao wenjian, January 1st 2004.

7. There had previously been some local attempts to enrol migrants in trade unions, but it was the first time that the ACFTU made it its national priority, see reports on the Fourteenth National Congress of Chinese Trade Unions, http://14da.acftu.org.

8. "Sichuan jianli mingong susong tongdao" (Sichuan set up litigation channel for migrant workers), Zhongguo laodong wang, http://www.labournet.com.cn.

9. "Sichuan chutai zhidu gei mingonggongzi jaishang shuang baoxian" (Sichuan sets up a system to double the guarantee of migrant worker salaries), Zhongguo laodong wang, http://www.labournet.com.cn.

10. "Daode yu fa" (Morality and Law), programme broadcast on Sichuan TV ( Sichuan dianshitai), November 17th 2003.

11. Ibidem.

12. These typically Chinese organisations are set up by state organs that supervise them.

13. Interview with Mr Ma, leader of the West China Sichuan Relief Centre for Migrant Workers, May 2004.

14. Current Sichuan governor Zhang Zhongwei has expressed many times his commitment to protecting the interests and rights of migrant workers while encouraging surplus rural labourers to seek work outside. See for example, http:// china.org.cn/english/2004/Mar/89626.htm.

15. "Chengdu shiwei shuji Li Chuncheng: rang cheng xiang jumin tong fazhan gong fanrong" (Chengdu First Party Secretary Li Chuncheng: urban and rural dwellers to benefit from development on equal footing), http://www.sina.com.cn 
16. The Ministry of Labour and Social Security reported in its mouthpiece on NGOs' key role in improving migrant worker rights awareness, and cited the case of a female migrant worker who sued her employer for not giving her paid leave. See "Daixin xiujia guansi tuxian falü kongbai" (Litigation over paid leave exposes hole in the law), Zhongguo laodong baozhang baogao (China Labour and Social Security News), August 26th 2004.

17. The ones run by the Sichuan Province Women Federation, the West China Sichuan Relief Centre for Migrant Workers, and the Peking NGOs Migrant Women's Club and Beijing Facilitator.

18. Survey made by L. in twenty factories in Shenzhen Longgang township Longdong district from fall 2003 to fall 2004, Sunzhao zizhu huzhu kongjian (Searching for a space for autonomy and mutual aid), unpublished paper presented at Beijing Facilitator's conference. Also Liu Kaiming, op. cit.

19. Interview with $\mathrm{Mr} \mathrm{Wu}$ Xiangyu, head of Sichuan province leading group for the development of the workforce, November 25th 2003 and H., Nongmingong zizhu kongjian (Migrant Workers' Space for Autonomy), unpublished paper presented at Beijing Facilitator's conference in November 2004.

20. "Nanjing 20 taoxin bei da" (20 migrants claiming back pay are beaten in Nanjing), Mingpao, November 21st 2004, p. A16.

21. See for example the case of $\mathrm{Hu}$ Weiguo who was murdered for chasing Hubei Xiaogang Construction for 120,000 yuan overdue wages for two years owed to his team of 70 workers. The case was never solved. Josephine Ma, "Wife battles for pay her husband never saw", South China Morning Post, January 20th 2004, p. A4; "Mingong taoqian cusi gongdi" (Migrant claiming back pay suddenly died on construction site), Xinjingbao (The Beijing News), January 3rd 2004, http://www.thebeijingnews.com/ 2004-1-3/20041363141.htm; "Cusi minggong fayi jianding jieguo weichu” (Autopsy result of the migrant who suddenly died hasn't been released yet), The Beijing News, January 4th 2004, http://www.thebeijingnews.com/2004-1-4/200414674751.htm; "Taoxin minggong cusi gongdi zhuizongtiben paichu bei sha hou gaozhui keneng" (An investigation into the sudden death of a migrant on a construction site discards the possibility that he fell from the crane after having been killed), The Beijing News, January 10th 2004, http://www.thebeijingnews.com/2004-1-10/200411091205.htm. 22. Fu Jing, "Zeng : Pay all owed wages to migrants", China Daily, August 26th 2004, p. 1. 23. " 40 mingong jiao mantou tao gongzi" ( 40 migrants claim back pay chewing bread), The Beijing News, February 12th 2004, http://www.thebeijingnews.com/ 2004-1-12/200421243545.htm; "mingong shang tadiao taoxin" (Migrant hangs from a crane to claim back pay), The Beijing News, January 17th 2004, http:// www.thebeijingnews.com/2004-1-17/200411742804.htm; "Mingong taoqian shang le taodiao jizhe bulai ta jiu pao" (Migrant claiming back paid wages jumps from the crane where he was waiting for journalists to come), Sichuan xinwen wang, http:// www.newssc.org, March 24th 2004

24. "Ling yi ge jiaodu kan guoji weiquan" (Revised judgment on extreme actions to protect one's rights), Zhongguo funü bao (China Women's News), October 19th 2004, p. 5. 25. "Mingong jiaoxin zifen" (Migrant claiming back pay sets fire to himself), Mingpao, January 10th 2004, p. A22; Josephine Ma, "Workers face a long wait for justice”, South China Morning Post, January 21st 2004.

26. "500 mingong gongzi renwei nadao shou" (500 migrants have still not received their salaries), The Beijing News, December 30th 2003; “500 mingong qianxin anzaoyu 
zhixing nan" (Sentence over 500 migrants' back pay case hard to enforce), The Beijing News, January 10th 2004, www.thebeijingnews.com.

27. CCTV 1, December 4th 2003.

28. The state keeps issuing directives to protect migrants, which tends to prove the relative inefficiency of the previous campaigns, see "Guowuyuan liu cuoshi baozhang mingong" (State Council's six measures to protect migrants), Wenweipo, November 11th 2004, p. A10; Josephine Ma, "Make sure migrant workers get paid", South China Morning Post, January 8th 2005, p. A6.

29. H., Migrant Workers' Space For Autonomy, op. cit.

30. Zhang Zhiqiang, "Jiannan de weiquan zhi lu" (The difficult road toward rights' protection), Dagongmei zhi jia tongxun (Home of Female Migrants Journal), No. 3, May 2004, p. 6.

31. Neil J. Smelser, Theory of Collective Behavior, New York, Free Press of Glencoe, 1963, quoted by Charles Tilly, op. cit., p. 4.

32. James C. Scott, Weapons of the Weak: Everyday Forms of Peasant Resistance, New Heaven, Yale University Press, 1985, p. 336.

33. Ibidem, p. 338.

34. See for example Révo. Cul. dans la Chine pop., Anthologie de la Presse des gardes rouges, Paris, Bibliothèque asiatique, 1975, pp. 25, 54.

35. Vivienne Shue, “Legitimacy Crisis in China?", in Peter Hays Gries and Stanley Rosen (eds.), op. cit., pp. 24-49.

36. "Meizhi haiyan dianzi chang gongren wei jiejue xinjin wenti zuochu guoji xingwei dulu sunhai gongzong liyi" (Workers from Meizhi Haiyan electronic factory resort to extreme actions and block the road in an attempt to solve a dispute over salaries) Shenzhen wanbao (Shenzhen Evening), October 8th 2004, p.A5

37. "Tamen weihe yao dulu tao shuofa" (Why do they have to block the road to seek an explanation?),

Nanfang dushi bao (Southern Metropolis News), October 8th 2004, http://www.nanfangdaily.com.cn/ southnews/spqy/shiping/200410080133.asp

38. See cases 1,2,3 and 16 developed by Anita Chan in China's Workers Under Assault, The Exploitation of Labor in a Globalizing Economy, New York: M.E. Sharpe, 2001.

39. See for example "San qian yuangong yong feifa shouduan weiquan biaoming le shenme" (Three thousand workers and employees are using illegal means to protect their rights, what does it show?), http://www.rednet.com.cn; "Yue gongzi jin you 230 yuan, weihe yizhi wu ren guan?" (Why does nobody care when monthly salary is only 230 yuan?), http://www.help-poverty.org.cn/helpweb2/zhuyeneirong/e76.htm; "Cong zuoxiu dao zaofan, shei zai jinbu" (From demonstration to rebellion, who is making progress?), http://comments.szonline.net.

40. Interview with Jane Liu, Assistant Executive Director of the Institute of Contemporary Observation, November 4th 2004.

41. Chen Hong, "Shenzhen firm fined for low salaries", China Daily, December 10th 2004, p. 3; Chow Chung-Yan, "Electronics firm fined $1.96 \mathrm{~m}$ yuan over low wages", South China Morning Post, December 9th 2004, p. A4.

42. Interview with female migrant worker L., Shenzhen, December 4th 2004; see also Anita Chan, "Recent Trends in Chinese Labour Issues- Signs of Change", China Perspectives, No. 57, January-February 2005, pp.23-32.

43. Nanfang dushibao, October 12th 2004, www.nanfangdaily.com.cn.

44. Charles Tilly, op. cit., p. 10. 
45. Interview with Mr Ao and Mr Ma, leaders of the Pengzhou municipality Danjing Shan township Labour Association for Migrant Workers, November 1st 2004.

46. Mrs Pei Qinkun's presentation at a meeting held by Chengdu Migrant Workers Support Network in Chengdu on October 26th 2004.

47. Disabilities are classified from level 1 to level 10, level 1 representing the most serious degree of invalidity.

48. Gongshang baoxian tiaoli issued by the State Council in 2003, implemented by Chengdu municipality on January 1st 2004.

49. Survey at Guojiaqiao Labour market, Chengdu, November $2^{\text {nd }} 2004$.

50. Minban feiqiye danwei dengji guanli zanxing tiaoli (Provisional Regulations for Registration and Management of Popular Non-enterprise Work Units), published by the State Council in 1998. An English translation of these regulations can be found on the following website: http://www.chinadevelopmentbrief.com.

51. See Chloé Froissart, Quelles possibilités pour négocier un nouveau contrat social en Chine? L'exemple des ONG au service des travailleurs migrants, paper presented at the Asia Network Congress, Paris, September 29th 2005, http://www.reseau-asie.com/cgi-bin/prog/ pform.cgi?langue $=$ fr $\&$ Mcenter $=$ colloque $\&$ TypeListe $=$ showdoc $\&$ email=\&password=\&ID_document $=260$

52. Interview of the author with this NGO's leader and other migrant volunteers, Shenzhen, December 4th, 2004.

53. Jean-Philippe Béja, “The Evolving concept of 'Civil Society' in China”, paper presented at AAS. Chicago, April 1st 2005, p. 17.

\section{RÉSUMÉS}

Over the past few years, as conflicts involving migrant workers have become more and more frequent, the Chinese state has called for the protection of their rights, but with the effect of abetting the rise of social movements. New statements made by the state legitimated migrants' claims. More aware of their rights, migrants, as never before gradually became attuned to their relationship to the political system. While the state is now increasing their access to public institutions and party organisations, migrants deem these measures inefficient, and the result is demonstrations or new forms of mediation and representation. Yet this development does not represent a significant change in state-society relations. 